RU Особенности инварианта татарской советской драматургии 1920-1930-х годов (на примере пьес Г. Ибрагимова и К. Тинчурина)

Шарипова А. С.

\begin{abstract}
Аннотация. Цель статьи - определить особенности инварианта татарской советской драматургии 1920-1930-е годов. Научная новизна заключается в попытке выявления закономерностей идейноэстетического развития национальной сценической литературы исследуемого периода через призму инварианта. Полученные результаты свидетельствуют о том, что после октябрьской революции 1917 года происходит смена художественных парадигм в татарской драматургии, которая приводит к значительному отрыву от национальных и общечеловеческих идеалов. Как показывает анализ драмы Г. Ибрагимова «Яңа кешеләр» («Новые люди», 1920), а также комедии К. Тинчурина «Жилкәнсезләр» («Без ветрил», 1926), в которых в наиболее полной мере были представлены принципы создания новых советских пьес, характерными особенностями формирующегося инварианта татарской драматургии становятся пропаганда идеи «строительства новой жизни», наличие конфликта, основанного на классовой борьбе; четкое деление персонажей на положительных и отрицательных героев; художественное сочетание реалистических тенденций с элементами революционной романтики; превосходство пролетарского гуманизма над общечеловеческим гуманизмом. Художественные традиции национальной драматургии начала XX века в полной мере сохраняются только в эмигрантской литературе.
\end{abstract}

\title{
EN Soviet Tatar Dramaturgy of the 1920-1930s (by the Example of the Plays by G. Ibragimov and K. Tinçurin)
}

\author{
Sharipova A. S.
}

\begin{abstract}
The paper aims to reveal the peculiarities of Soviet Tatar dramaturgy of the 1920-1930s. Scientific originality of the study lies in the fact that that the author analyzes ideological and aesthetic principles of national scenic literature development in the mentioned period through the prism of invariant. The findings indicate that after October revolution of 1917 Tatar dramaturgy experienced a change of artistic paradigms which results in the refusal of national and universal human values. The analysis of G. Ibragimov's drama “Яңа кешеләр” (“The New People”, 1920) and K. Tinçurin’s comedy “Жилкәнсезләр” (“Unmoored”, 1926), the most striking examples of "new Soviet plays", allows identifying the typical features of forming Soviet Tatar dramaturgy: propagation of "building a new life"; conflict based on class struggle; strict division between positive and negative personages; artistic integration of realistic trends and elements of revolutionary romanticism; prevalence of proletarian humanism over the universal one. National dramaturgic traditions of the beginning of the XX century fully survived only in émigré literature.
\end{abstract}

\section{Введение}

После октябрьской революции 1917 года происходит смена идеологических ориентиров и художественных парадигм в литературе, в результате чего начинает сформировываться инвариант художественной концепции социалистического реализма, который в первую очередь находит отражение в наиболее близкой к читателю-зрителю массовой форме литературного творчества - драматургии. «Поскольку “разрушение капиталистического мира” сопровождалось коренным изменением общественного строя, усилилась идеологическая функция литературы и искусства, драматургия и театр также должны были получить иное содержание, иную форму, войти в “революционный” облик» (Ханзафаров, 2014, с. 333). Актуальность настоящей статьи объясняется тем, что выявление особенностей инварианта татарской драматургии, сформированного в 1920-1930-х годах, может послужить основой для дальнейшего исследования татарской советской сценической литературы в аспекте «инвариант-поэтический мир». 
Для достижения вышеуказанной цели поставлены следующие задачи: 1) сделать краткий обзор общих тенденций развития татарской драматургии в 1920-1930-х годах; 2) проанализировать драму Г. Ибрагимова «Яңа кешеләр» («Новые люди», 1920) и комедию К. Тинчурина «Жилкәнсезләр» («Без ветрил», 1926), наиболее полно отразивших характерные особенности татарской драматургии исследуемого периода; 3) на основе анализа пьес сформулировать основные идейно-эстетические особенности татарской советской драматургии 1920-1930-х годов.

Теоретическую базу составили научные труды литературоведов А. Ахмадуллина (Ахмадуллин, 2012; Әхмәдуллин, 1980; Әхмәдуллин, 2002), Д. Загидуллиной (Загидуллина, 2016), А. Закирзянова (Закиржанов, 2012), А. Салиховой (Салихова, 2016), Н. Ханзафарова (Ханзафаров, 2014), М. Хасанова (Хасанов, 1987). В качестве методов исследования применялись культурно-исторический и герменевтический методы, метод целостного анализа художественного произведения. Практическая значимость работы определяется возможностью использования материалов в фундаментальных трудах по истории татарской литературы, на курсах по татарской драматургии в вузах, а также при составлении учебников и методических пособий по данной теме.

\section{Основная часть}

Развитие драматургии в 1920-1930-х годах связано с художественным отражением общественных преобразований, характеризующихся острым противостоянием сторонников и противников советской власти в годы Гражданской войны и коллективизации сельского хозяйства. Вместе с тем необходимо отметить, что общая картина в татарской сценической литературе после октябрьской революции несколько отличалась от сложившейся ситуации в русской драматургии. Это было связано, прежде всего, с общим состоянием татарской литературы, в которой вплоть до 1920-1930-х годов сохранились просветительские мотивы, а также «опозданием» формирования татарского сценического искусства. Несмотря на то, что тематика пьес исследуемого периода была весьма разнообразной - классовая борьба в период Гражданской войны, восхваление и пропаганда идеологии новой власти, борьба за победу новых отношений в деревне и в среде творческой интеллигенции, высмеивание традиционного образа жизни татарского народа, антирелигиозная тема, социальное раскрепощение женщины и другие, - в основу драматических произведений авторами была заложена единая идея - это отрицание «прошлого», утверждение «нового», что достигалось в основном через нравоучение. Поэтому первые пьесы, написанные сразу после революций 1917 года по новым идеологическим требованиям на социально-политическую тематику, отличаются схематичностью, они далеки от действительности, от живых образов. Речь идет о таких историко-революционных и героических драмах, как «Беренче таң» («Первая заря», 1917) Габдерауфа Ниязбаева, «Канлы көннәрдә» («В кровавые дни», 1919), «Беренче адым» («Первый шаг», 1919) Шамиля Усманова, «Дошманнар» («Враги», 1920) Фатиха Сайфи-Казанлы и др.

Ввиду того, что уже в первые годы революции и Гражданской войны не только в городах, но и в частях Красной Армии были сформированы многочисленные самодеятельные драматические труппы, репертуар которых подбирался с учетом пропагандистских задач, драматурги, увидев смысл творческой деятельности в служении советской власти, в 1920-х годах начали увлекаться написанием пьес в виде агитплакатов, в которых четко и откровенно показывалась классовая борьба, преобладали революционный пафос, гипертрофированная идейность и социальная заостренность. К таковым можно отнести пьесы «Кызыл йолдыз» («Красная звезда», 1923), «Коммунага» («В коммуну», 1924) М. Файзи, «Күчү чорында» («В эпоху перемен», 1926) А. Тагирова, «Кызыл йолдыз» («Красная звезда», 1925) М. Гафури, «Хәжәйкә» («Хозяйка», 1926) Ш. Мустая, «Ун ел тулганда» («Когда исполнялось десять лет», 1927), «Биш меңле Гайнетдин» («Пятитысячный Гайнутдин», 1928) А. Камала, «Пожар» (1929) Р. Ишмурата и другие. Вместе с тем, несмотря на разнообразие имен, татарская сценическая литература на этом агитационном материале не смогла продолжить свое развитие: большинство пьес оказались «однодневками» пропагандистского толка.

На наш взгляд, в определении особенностей формирующегося инварианта татарской советской драматургии важную роль сыграла драма известного татарского писателя, литературного критика, публициста, политического и общественного деятеля Галимджана Ибрагимова «Яңа кешеләр» («Новые люди», 1920). Первое и единственное драматическое произведение татарского классика, являющегося одним из основателей татарской советской литературы, видимо, создавалось с целью исправления ситуации в татарской драматургии.

Пьеса «Новые люди» стала весьма ярким примером произведения, «изображающего борьбу новых людей, строящих новое общество, становление которых идет через их серьезные внутренние противоречия» (Закиржанов, 2012, с. 67). Как видно, уже название произведения показывает, что драма является результатом глубокого поиска автором совершенно новой концепции, способной воспроизвести основную идею пьесы - это призыв к изменениям устоявшихся укладов жизни, преобразованию мира, борьбе за создание «нового». «Г. Ибрагимов называет борцов, созданных революцией и сделавших революцию, “новыми людьми”, видит особенность и превосходство новой эпохи прежде всего в таких героях» (Әхмәдуллин, 1980, с. 170). Тщательный подбор имен персонажам также усиливает этот замысел: имя главного героя драмы «Батырхан» означает «смелый правитель», «герой», имя «Тимеркай» образовано от слова «тимер», то есть «железо», имя «Камар» означает «луна». Используя литературный прием, часто встречаемый в татарской просветительской литературе, Г. Ибрагимов акцентирует внимание на назначении персонажей, усиливает их смысловую нагрузку.

В драме, состоящей из трех действий, изображены драматические события, происходящие в татарской деревне в годы Гражданской войны. Конфликт пьесы в соответствии с канонами идеологии основан на классовой борьбе. «Все персонажи в зависимости от их классовой позиции сгруппированы в два лагеря, выступая 
либо защитниками, либо врагами советской власти. Личные судьбы героев решаются в острых классовых схватках, в горниле великих социально-исторических перемен» (Хасанов, 1987, с. 170). Автор «причинами борьбы определяет социальное неравенство и стремление к национальной свободе, подчеркивает, что только такой борьбой новые люди, то есть Батырхан, учительница Камар, смогут обеспечить светлое будущее для страны» (Жизнь и творчество..., 2017, с. 225).

Главный герой пьесы - красный командир Батырхан - прошел противоречивый путь до прихода в ряды революционеров: был сослан на семь лет на каторгу за убийство Саткая, отстаивая честь своей невесты, дочери сельского богача Хайри Зайнии, участвовал в Первой мировой войне. В драме Батырхан представлен борцом со стойким характером, однако ему не чужды и человечность, и внутренние переживания. Разговор Батырхана с односельчанином Шайбеком доказывает это:

Б а m ы р х а н. Их, бабай, ни эшлик, ни генә эшлик?! Син үзең дә беләсең бит, зарарлы чүпне утап ташламасаң, ул бөтен жирне каплап, ашлыкны харап итә!.. (Авыр хәлдә торып, бабайның кулына тотына.) Жан кыю безгә дә уен түгел, бабай... <...> Безгә дә, безнең эшче-крестьян халкына да контрреволюционерларның башлары өстенндн азатлыкка барырга туры килә... Башка юл юк... Юк, бабай... <... Юл бер генә! Менә шушы канлы юл изге юл (Ибраһимов, 2018, с. 424)! / Б а т ы р х а н. Эх, дедушка, что делать нам, что же делать?! Ты ведь и сам знаешь: если не прополоть сорную траву, она прорастет везде и угробит хлеб!.. (Тяжело поднимается, берет старика за руку.) Лишать человека жизни и нам нелегко, дедушка... <...> Нам тоже, рабочему и крестьянину, приходится идти к свободе по головам контрреволюционеров. <... Другого пути нет... Нет, дедушка... <...> Только один путь! Вот этот кровавый путь - священный путь! (здесь и далее перевод автора статьи. - А. Ш.).

Таким образом, Г. Ибрагимовым создается образ нового драматического героя, сочетающего в себе классовое и общечеловеческое. Кроме этого, драматург, включив образ советской девушки - учительницы Камар, показывает динамику становления женских характеров в новых исторических условиях, логику роста сознательности и социальной раскрепощенности этих женщин:

К $\boldsymbol{a}$ м ә р. ...мин бик артык ярлы гаилддәнмен. Мең газап белән укыдым. Иске тормышның барлык «хозурларын» үз йөрәгемдә татыдым... <... ...мин беренче сөюмдә тирән бер бәхетсезлек күрдем... Шуның газабыннан дөньяны ташлап, кайгымны күмәр, бераз онытылыр өчен, Уфага курсларга язылдым... Хәзер... Хәзер юлым, кыйблам билгеле, жаным тыныч... Элек сөюләр, матур чүпрәкләр колы булуымны уйласам, хәзер үземнең йөзем кызара (Ибраһимов, 2018, с. 408)... / К а м а р. ...я из очень бедной семьи. Училась с большим трудом. Все «прелести» старой жизни я испробовала... <... ... я увидела в своей первой любви глубокое несчастье... <... Чтобы забыть о том горе, которое постигло меня, записалась на курсы в Уфу... Теперь... Теперь мой путь, мое направление определены, моя душа спокойна. <...> Если подумаю, что была рабой любви, красивых тканей, теперь мое лицо краснеет...

Образованная, жизнелюбивая, целеустремленная Камар, отказавшись от всех личных благ, посвятила себя борьбе за всеобщее счастье:

К $\boldsymbol{a}$ м ә р. Дошман жиңелер... Бу кан түгүләр бетәр... Жир йөзе гөл бакчасына дйләнер... Адәмнәр матур, бәхетле тора башларлар (Ибраһимов, 2018, с. 410). / К а м а р. Враг будет побежден... Закончатся эти кровопролития... Земля превратится в цветущий сад... Люди станут жить красиво и счастливо...

Как известно, мотив отказа от личных интересов ради общего дела, интересов большинства достаточно часто встречался и в дореволюционной драматургии, к примеру, в пьесах Г. Кулахметова «Яшь гомер» («Молодая жизнь»), Я. Вали «Голод заставил», Г. Исхаки «Мөгаллимә» («Учительница»), М. Файзи «Кызганыч» («Жалко») и др. Однако в 1920-х годах он обретает совершенно иное решение: если раньше герой жертвовал личными интересами ради благополучия других и тем самым был обречен на несчастье, то в пьесах советского периода такой герой, отказываясь от личных благ, постигает смысл бытия, находя удовлетворение в борьбе. Именно таким образом разрабатывалась эта идея Г. Ибрагимовым и его современниками в свете позиций революционного аскетизма. Она предлагалась как одно из главных качеств новых героев.

Требует особого внимания также образ молодого деревенского парня Тимеркая. Он вспыльчив, глубоко ненавидит неравенство, несправедливость. Особенности его характера объясняются тем, что Тимеркай с детства остался сиротой и выполнял роль слуги у своего родного деда. Враждебное отношение к противоположному классу, однобокое понимание целей борьбы приводит к тому, что он расстреливает даже своего дядю Вали. Оценка его действиям звучит в реплике рассудительного старика Абдераш:

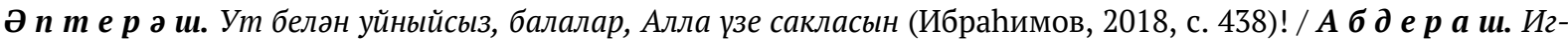
раете с огнем, дети, пусть хранит вас Аллах!

Как видно, классовая борьба в драме предстает во всем многообразии социальных, психологических и политических мотивов. Тема революции раскрывается автором через изображение конкретных судеб, родственных отношений, показывается противоречивый путь становления революционной личности. Все это позволяет автору сохранять жизненную достоверность и реалистическую убедительность в драме, «органично сочетать реалистические и романтические тенденции, а также элементы агитационно-массового искусства» (Салихова, 2016, с. 90).

Во второй половине 1920-х годов в татарской сценической литературе начинает наблюдаться новая волна это переход на изображение в сатирическом плане недовольных слоев татарской буржуазии с происходящими изменениями в обществе. Интересна в этом плане сатирическая комедия «Жилкәнсезләр» («Без ветрил», 1926) Карима Тинчурина, охватывающая события 1910-1924 годов. Путем изображения судеб представителей татарской буржуазии и национальных общественных деятелей - интеллигента Батырхана, богатых торговцев Нуретдина, Мисбаха, генерала Носова, нэпмана Зайнетдина, спекулянта Фаттаха, представителя военного 
совета Сахипгарая, богача Наума Пахомича, имама мечети Хазрата, построения конфликта на идеологической борьбе касательно происходящих политических изменений в стране, автор отражает самые ответственные моменты в истории народа - период революций, первые годы советской власти.

Комедия «Без ветрил» примечательна тем, что в ней впервые появляются герои, не встречавшиеся до сих пор в татарской драматургии. Среди них особое место занимает сатирический образ татарского интеллигента Батырхана, думающего в любой ситуации только о своей личной выгоде, мечтающего добиться положения в обществе. Стремления в зятья к торговцу Нурутдину, становление большевиком, далее борьба против советской власти указывает на его беспринципность. Образ образованного, интеллигентного человека, который в пьесах дореволюционного периода изображался в основном в качестве положительного героя, в этой комедии представляется в новом ракурсе, позволяющем показать драматургу неоднородность интеллигенции как сословия. Как видно, комедия полностью посвящена разоблачению представителей татарского буржуазного общества. Политические споры, бурные обсуждения героев относительно революции, новой власти, изменений в обществе показывают отсутствие единства взглядов, общих целей, понимания между ними. Название комедии «Жилкәнсезләр» («Без ветрил») также указывает на безнадежность их дальнейших судеб. Таким образом, «смех над представителями уничтожаемых классов, веселье над катастрофой национального масштаба, повлекшей гибель тысяч людей, изломавших судьбы многих поколений ни в чем не повинных мусульман, превратил комедию этого периода в чисто идеологическое оружие» (Салихова, 2016, с. 106).

Бесспорно, ярко индивидуализированные образы, оригинальные и глубоко жизненные ситуации, изображенные в пьесе «Без ветрил», обеспечивают широту эпического охвата явлений действительности, «органически связав изображения социальных процессов с глубоким раскрытием личных судеб героев» (Ахмадуллин, 2012, с. 192-193). Вместе с тем, несмотря на попытки автора затрагивать сложные и противоречивые проблемы своего времени, инвариант советской драматургии ограничивал творческий процесс, заставив подгонять схематизм образов под классовые показатели.

Безусловно, драматургия 1920-1930-е годов характеризуется не только односторонностью художественного изображения пьес. В истории татарской сценической литературы - это время и экспериментов, и поисков возможностей сохранить художественные традиции и достижения дореволюционного периода. В пьесах, показывающих прошлое татарского народа, были попытки изобразить романтическую картину при помощи музыки, фольклорно-этнографических сцен, а также воссоздания народных характеров на основе ранее сформированного инварианта художественной концепции мира и личности. Как пишет Д. Ф. Загидуллина, «романтические драмы и трагедии Ф. Бурнаша, К. Тинчурина и других авторов воспринимаются как продолжение традиций предыдущего этапа», и идеологическая составляющая, сочетаясь с национальными аспектами, воплощается в тематике, конфликтах и характерах драматических произведений начала 1920-х годов. К примеру, произведения Мирхайдара Файзи «Асылъяр» (1920), Карима Тинчурина «Казан сөлгесе» («Казанское полотенце», 1923), «Сүнгән йолдызлар» («Погасшие звезды», 1923), «Зәңгәр шәл» («Голубая шаль», 1926), отличающиеся поэтичностью и лиризмом, входят в «золотой фонд» национальной сценической литературы, поскольку в них представлены национальные философия и эстетика, менталитет и характер (Загидуллина, 2016, с. 9). Умелое использование национальных литературных традиций, динамичность событийного ряда, индивидуальность языка персонажей, лиричность обеспечили богатство и многогранность поэтического мира этих произведений. Вместе с тем уже в начале 1920-х годов появились случаи обвинения драматургов в идеализации и романтизации дореволюционной жизни, в антинародности и отсутствии классового подхода. Например, еще в 1921 году М. Файзи приглашали поставить свои пьесы, а затем отказали, как он сам подумал, по идеологическим соображениям (Файзи, 1957, с. 427).

Таким образом, традиции изображения поэтического мира татарской классической литературы дооктябрьского периода, проявляющиеся в форме основной идеи, касающейся судьбы нации, общечеловеческих ценностей, начинают вытесняться формирующимся инвариантом советской драматургии на периферию. Исключениями стали лишь драматические произведения, написанные в эмиграции, как пьесы Гаяза Исхаки «Среди волн» («Дулкын эчендә», 1920), «Между двух огней» («Ике ут арасында», 1920), «Жан Баевич» («Жан Баевич», 1923) и др. Они по художественному оформлению близки традициям национальной драматургии начала XX века: «...в их основу заложены проблемы, касающиеся судьбы татарской нации, которые советская драматургия не в состоянии была ставить и решать» (Әхмәдуллин, 2002, с. 32).

\section{Заключение}

Поводя итог, можем сказать следующее: после революций 1917 года татарская драматургия попадает в сферу действия новой культурной парадигмы социалистического общества, которая приводит к значительному отрыву от национальных и общечеловеческих идеалов. Как показывает анализ драмы Г. Ибрагимова «Яңа кешеләр» («Новые люди»), а также комедии К. Тинчурина «Жилкәнсезләр» («Без ветрил», 1926), в которых в наиболее полной мере были представлены принципы создания новых советских пьес, характерными особенностями инварианта татарской советской драматургии 1920-1930-х годов становятся пропаганда идеи «строительства новой жизни», наличие конфликта, основанного на классовой борьбе; четкое разделение персонажей на положительных и отрицательных героев; художественное сочетание реалистических тенденций с элементами революционной романтики; превосходство пролетарского гуманизма над общечеловеческим гуманизмом; определенная схематичность в художественном изображении отрицательных героев. Несмотря на определенные попытки расширения тематических границ, создания народных характеров, используя 
фольклорно-этнографические мотивы, основная тема - строительство новой жизни - уводит сценическую литературу от этнической направленности, как в содержании, так и в поэтике. Художественные традиции национальной драматургии начала XX века в полной мере сохраняются только в эмигрантской литературе.

Перспективы дальнейшего исследования проблемы мы видим в комплексном изучении истории развития татарской драматургии в аспекте «инвариант-поэтический мир».

\section{Источники | References}

1. Ахмадуллин А. Г. Татарская драматургия: история и проблемы. Казань: Татар. кн. изд-во, 2012.

2. Жизнь и творчество Галимджана Ибрагимова. Казань: ИЯлИ, 2017.

3. Загидуллина Д. Ф. Татарская литература и национальный театр: одна дорога на двоих // Театр XXI века и вызовы нового времени: материалы Международной научно-практической конференции, посвященной 110-летию татарского театра. Казань: ИЯЛИ, 2016.

4. Закиржанов Ә. М. Г. Ибраһимовның «Яңа кешеләр» драмасында яңа чор ижат концепциясе чагылышы // Г. Ибраһимов мирасы һәм төрки дөнья: Г. Ибраһимовның тууына 125 ел тулуга багышланган Халыкара фәнни-гамәли конференция материаллары (17 апрель, 2012 ел). Казан, 2012.

5. Ибраһимов Г. Г. Әсәрләр: 15 томда. Академик басма. Казан: Татар. кит. нәшр., 2018. Т. 3. Хикәя, повестьлар, роман, драма / төз., текст., иск. һәм аңл. әзерл. Г. Н. Зәйниева, Г. Г. Батыршина.

6. Салихова А. Р. Особенности формирования и развития татарского сценического искусства. Казань: ИЯЛИ, 2016.

7. Файзи М. Сайланма әсәрләр: 2 томда / төз. С. Фәйзуллин. Казан: Татар. кит. нәшр., 1957. Т. 2. Пьесалар, шигырьләр, көндәлек дәфтәреннән өзекләр.

8. Ханзафаров Н. Драматургия // Татар әдәбияты тарихы: сигез томда / төз. Р. Ф. Рахмани. Казан: Татар. кит. нәшр., 2014. Т. 5. 1917-1956 еллар / фәнни мөх. Д. Ф. Заһидуллина.

9. Хасанов М. Писатель, ученый, революционер. Казань: Таткнигоиздат, 1987.

10. Әхмәдуллин А. Г. Ибраһимов һәм татар драматургиясе // Сәхнә әдәбияты һәм тормыш. Казан: Тат. кит. нәшр., 1980.

11. Әхмәдуллин А. Г. Офыклар киңәйгәндә. Казан: Татар. кит. нәшр., 2002.

\section{Информация об авторах | Author information}

RU Шарипова Алсу Самигулловна ${ }^{1}$, к. филол. н.

${ }^{1}$ Институт языка, литературы и искусства имени Г. Ибрагимова Академии наук Республики Татарстан, г. Казань

EN Sharipova Alsu Samigullovna ${ }^{1}, \mathrm{PhD}$

${ }^{1} \mathrm{G}$. Ibragimov Institute of Language, Literature and Art of the Tatarstan Academy of Sciences, Kazan

${ }^{1}$ alsu-samigullovna@yandex.ru

\section{Информация о статье | About this article}

Дата поступления рукописи (received): 18.08.2021; опубликовано (published): 29.10.2021.

Ключевые слова (keywords): татарская драматургия; инвариант; Г. Ибрагимов; К. Тинчурин; Tatar dramaturgy; invariant; G. Ibragimov; K. Tinçurin. 